\title{
The benthic invertebrate fauna of the Peel-Harvey Estuary of south- western Australia after completion of the Dawesville Channel
}

\author{
Corey S. Whisson ${ }^{1 *}$ Fred E. Wells ${ }^{2}$ and Tom Rose ${ }^{3}$ \\ 'School of Environmental Biology, Curtin University of Technology \\ GPO Box U 1987, Perth, Western Australia 6001, Australia \\ ${ }^{2}$ Western Australian Museum, Francis Street \\ Perth, Western Australia 6000, Australia \\ ${ }^{3}$ Water and Rivers Commission, Aquatic Sciences Branch, \\ 3 Plain Street, East Perth, Western Australia 6004, Australia \\ - Present address: Western Australian Museum, Francis Street, Perth, Western Australia 6000, Australia
}

\begin{abstract}
During the 1970's the Peel-Harvey Estuary experienced severe symptoms of nutrient enrichment. There were large inputs of nutrients to the system, and only limited oceanic flushing occurred, via the long, narrow Mandurah Entrance Channel. In 1994 the Dawesville Channel was constructed to increase oceanic flushing within the Peel-Harvey Estuary; reduce the occurrence of toxic phytoplankton blooms (eg. blue-green Nodularia spumigena) and decrease macroalgal growth. The present paper compares the benthic invertebrate fauna in the Peel-Harvey Estuary before and after the Dawesville Channel was constructed.

One hundred sediment cores were collected during early autumn and late winter 2000 , yielding a total of 17,443 benthic invertebrates, comprising 52 species. Polychaetes, molluses and crustaceans dominated species richness and density in both seasons. There was a clear difference in benthic invertebrate species richness and density between seasons. During early autumn, benthic invertebrate communities in the Peel-Harvey Estuary had a low species richness ( 27 species), but this increased substantially ( 46 species) in late winter. Total mean density quadrupled from $6397 \mathrm{~m}^{-2}$ in early autumn to $26,180 \mathrm{~m}^{-2}$ in late winter. The increased species richness was due to increases in small crustaceans with a short lifespan and, to a lesser extent, chironomid insect larvae. With the exception of one site, the increased density was general throughout both Peel Inlet and the Harvey Estuary. There was no apparent correlation between increased densities and proximity to the entrance channels.

Pre-Dawesville Channel data on benthic invertebrates are few. Molluscs provided the best comparisons between pre and post Dawesville Channel benthic invertebrates. In the late 1970's mollusc diversity was low and was dominated by two small estuarine species: the bivalve Arthritica semen and the gastropod Hydrococcus brazieri. A two-year study at one site in Peel Inlet recorded a maximum density of $45,491 \mathrm{~m}^{2}$ for $A$. scmen and $19,959 \mathrm{~m}^{-2}$ for $H$. brazicri. By the 1980's the density of both species had declined; H. brazieri had nearly disappeared from the Peel-Harvey Estuary. In 2000, the mean densities of $A$ semen and $H$. brazien remained low. Several marine species that were recorded in the post Dawesville Channel samples were not recorded in the 1970 's. Data suggests that the Peel-Harvey Estuary has become more marine, and that increased recruitment of planktonic larvae through the short, narrow Dawesville Channel and improved water quality has probably enabled these species to establish themselves. All of these species were recorded in very low densities, and they have not established the dense populations previously attained by $H$. brazieri and $A$. semen.
\end{abstract}

Key words: Benthic invertebrates, Peel-Harvey Estuary, Dawesville Channel, Western Australia.

\section{INTRODUCTION}

Estuaries in south-western Australia are generally small, and their physical and geomorphological characteristics make them particularly susceptible to human impacts (Hodgkin and Lenanton, 1981). While the catchments may have large areas, rainfall is low and water volumes in river inflows are small by world standards. As the river reaches the coastal 
plain, many estuaries broaden into shallow lagoons. The lagoons are sedimentary and there are often few hard substrates or rocky bottoms for organisms to colonise. A narrow entrance channel to the sea often restricts tidal flow into and out of the estuary (Hesp, 1984; Hodgkin and Hesp, 1998). Tides in the southwest are microtidal, ranging up to $1 \mathrm{~m}$ over the year, but averaging $0.3 \mathrm{~m}$ or less on each tidal cycle (Hodgkin and DiLollo, 1958). Many estuaries have a sand bar across the mouth which restricts water exchange from several months through to years, until the bar is broken; some bars have become permanent, while others are kept permanently open by human intervention (Hodgkin and Hesp, 1998).

The combination of a low riverine input; a large lagoon; narrow channel to the sea, and small tidal amplitude, all serve to minimise exchange between south-western Australian estuaries and the sea, thus concentrating contaminants, mainly nutrients, in the estuaries (Hodgkin and Hesp, 1998).

Rainfall in the southwest is strongly seasonal and Mediterranean, with most occurring from late autumn to early spring (May to September). Estuarine salinities during winter are low, often falling to as low as 3\% over broad portions of the lagoons and basins, and remaining at those levels for weeks. As rivers cease to flow in spring, tidal intrusion combined with increased evaporation from greater day length and air temperatures, cause the estuaries to become more saline. Hypersaline $(>45 \%$ ) conditions and high water temperatures can occur over most of the summer and early autumn (Hodgkin and Lenanton, 1981).

As with several other south-western Australian estuaries, the Peel-Harvey Estuary $\left(32^{\circ} \mathrm{S} ; 115^{\circ} \mathrm{E}\right)$ has been severely affected by nutrient enrichment. The system consists of the circular Peel Inlet, with an area of $75 \mathrm{~km}^{2}$, and the elongate Harvey Estuary, with an area of $61 \mathrm{~km}^{2}$ (Hodgkin and Lenanton, 1981; Figure 1). The two have similar mean volumes $\left(61 \times 10^{6} \mathrm{~m}^{3}\right.$ and $56 \times 10^{6} \mathrm{~m}^{3}$ respectively) and shallow water depths, averaging $0.8 \mathrm{~m}$ and $1.0 \mathrm{~m}$ respectively (McComb and Lukatelich, 1995). Historically, tidal exchange with the Indian Ocean was restricted by the long, narrow Mandurah Entrance Channel in the north of Peel Inlet, resulting in poor nutrient flushing from the PeelHarvey Estuary. As agriculture expanded in the catchment and fertiliser usage increased, nutrients progressively accumulated in the Peel-Harvey Estuary. This resulted firstly in large increases in benthic macroalgae followed later by seasonal blooms of harmful phytoplankton (toxic blue-green Nodularia spumigena). As a result of extensive environmental studies (eg. Rippingale, 1977; Wells et al., 1980; Hodgkin et al., 1985; Rose, 1994), a short, narrow channel was constructed through the coastal dunes in the northern Harvey Estuary. This channel, the Dawesville Channel, opened in April 1994 and was designed to increase oceanic flushing within the Peel-Harvey Estuary, raise salinities to create conditions unsuitable for harmful phytoplankton blooms, and decrease macroalgal growth.

The estuarine food chain typically consists of abundant and productive primary producers (macroalgae, seagrasses, and/or phytoplankton), which are grazed by primary consumers such as zooplankton, worms, molluscs, small crustaceans and fish. Benthic species often dominate invertebrate abundance and production in an estuary (Day, 1981; Hodgkin et al., 1985). While individual species may be abundant, species diversity is usually low (Barnes, 1974; McLusky, 1989). Benthic invertebrates are the food source for a wide variety of estuarine fish, large crustaceans and waterbirds, which in turn are available to higher trophic levels (Barnes, 1974; Day, 1981).

Prior to the opening of the Dawesville Channel, few benthic invertebrate species were able to tolerate the environmental conditions in the PeelHarvey Estuary. These were mainly small, shortlived opportunists that were highly productive (Rippingale, 1977; Wells et al., 1980; Chalmer and Scott, 1984; Rose, 1994). The opening of the Dawesville Channel increased water exchange with the sea and made the Peel-Harvey Estuary a more marine environment. Tides are now of similar amplitude to those along the coast and salinity is less variable. The present paper has two purposes: to characterise the present benthic invertebrate fauna of the Peel-Harvey Estuary and to examine changes which have occurred in the system as a result of the opening of the Dawesville Channel.

\section{MATERIALS AND METHODS}

Samples were collected from ten sites in Peel Inlet and the Harvey Estuary during early autumn (March) and late winter (August) 2000 (Figure 1). To allow direct comparisons, the sample sites and sampling regime were the same as those used in a study of molluscs in the late 1970's (Wells et al., 1980). Site 10 (Dawesville) was chosen to assess the immediate area of the Dawesville Channel. Most sites were $10-15 \mathrm{~m}$ from shore in water depths of approximately $0.5 \mathrm{~m}$. Site 1 (Coodanup), Site 4 (Robert Bay) and Site 6 (Caddadup) were 100m from shore as the water was extremely shallow. Site 5 (located in the mid-region of Peel Inlet) was approximately $2 \mathrm{~km}$ south of Site 1 and at a water depth of less than $1.5 \mathrm{~m}$.

Samples were collected using a $10.3 \mathrm{~cm}$ diameter PVC tube which was driven into the sediment to a depth of $20 \mathrm{~cm}$. Six replicates were taken at each site. Samples were sieved through a $0.5 \mathrm{~mm}$ mesh in the field. They were labelled and placed in $10 \%$ 


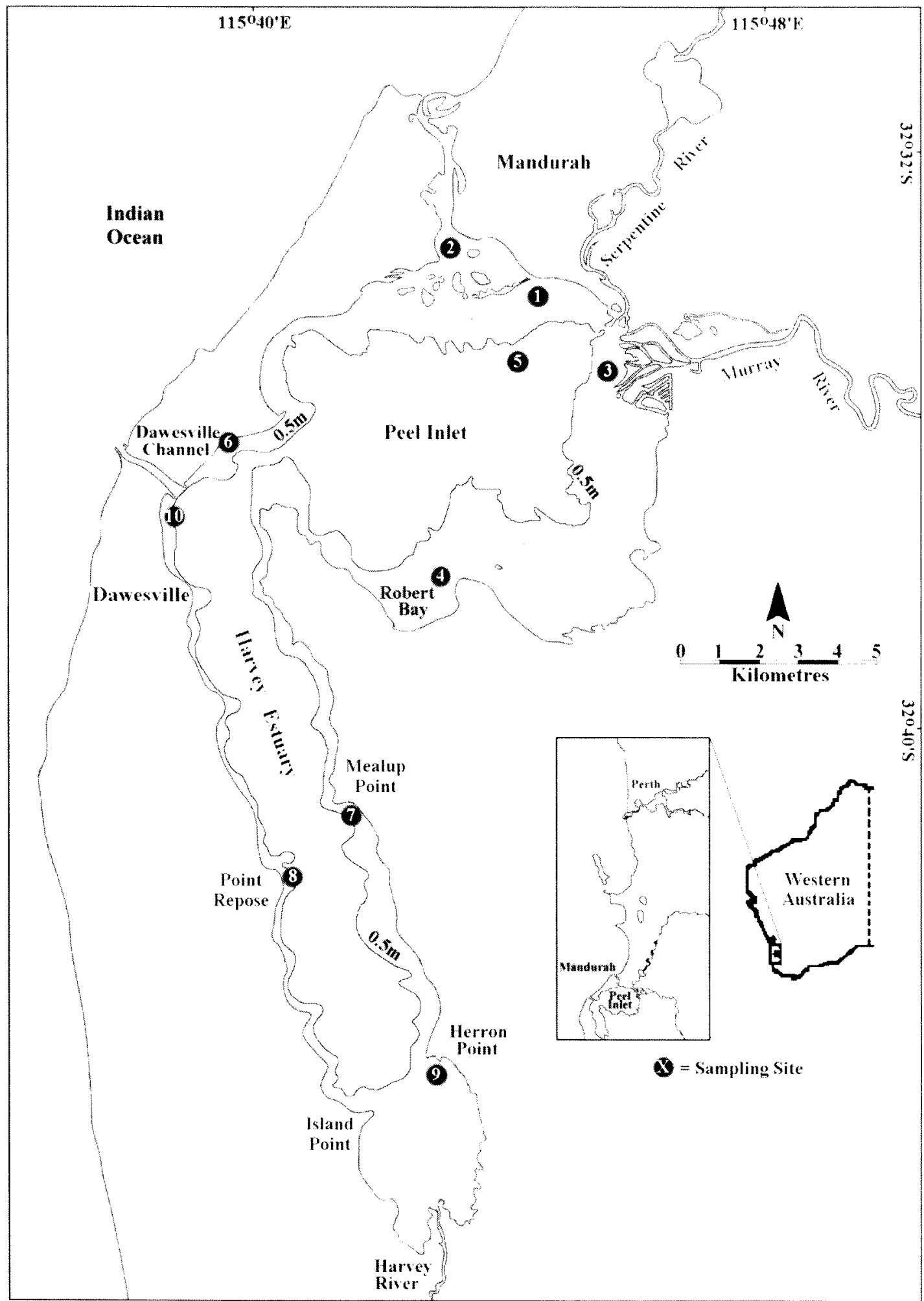

Figure 1 Map of sampling locations in the Peel-Harvey Estuary

formalin for two weeks before being transferred to $75 \%$ alcohol. In the laboratory, samples were sorted under a dissecting microscope. Any invertebrates that were alive when collected were removed, identified, counted and retained in $75 \%$ alcohol.

Surface and bottom water temperatures and dissolved oxygen concentrations were measured using an analog YSI 51A oxygen meter, and salinities were measured using an Atago S/Mill-E refractometer. Sediment samples were also collected for analysis of physical and chemical characteristics. The upper $10 \mathrm{~cm}$ of sediment was removed using clean PVC tubing and partitioned into two $5 \mathrm{~cm}$ halves before being stored on ice. One portion from each core was treated with $6 \%$ hydrogen peroxide for 48 hours to remove any 
organic matter, washed overnight, and dried at $60^{\circ} \mathrm{C}$ for 24 hours. Sediment grain size and frequency were then determined using a standard set of geological sieves and the Wentworth scale. Particulate organic matter in the remaining portion was determined by removing any macrophyte and animal material from the sediment, drying the sediment at $60^{\circ} \mathrm{C}$ for 24 hours and burning on ignition at $530^{\circ} \mathrm{C}$ for 16 hours, then weighing to the nearest $1 \mathrm{mg}$ (Holme and McIntyre, 1984). Five replicate cores using clean PVC tubing were taken to a depth of $10 \mathrm{~cm}$ at each site to determine redox depth as described by Rose (1994).

Dendograms were calculated using the IBM program PC Ord. This program groups sites by cluster analysis using average linkage based on Sorenson's Index of Similarity. Species diversity $\left(\mathrm{H}^{\prime}\right)$, evenness (E) and dominance (D) were calculated using the Shannon Weiner formula (Krebs, 1989).

\section{RESULTS}

\section{Physical and Chemical Data}

Salinity and temperature in the water column were variable between sampling periods (Table 1). All sites were hypersaline in early autumn. Salinity increased with distance from the Dawesville and Mandurah channels. During late winter, salinities were highest at sites located close to the channels, and in the eastern region of Peel Inlet. Salinities were low $(<16 \%)$ in the southern regions of Peel Inlet and the Harvey Estuary. In late winter, bottom salinities were generally the same ( $<1 \%$ difference) as at the surface except at Site 6, Site 4 and Site 9 (Herron Point), where they greatly exceeded those at the surface (up to $9 \%$ difference). The surface and bottom water temperatures at all sites varied seasonally, ranging from $23.5^{\circ} \mathrm{C}$ in early autumn to $14.0^{\circ} \mathrm{C}$ in late winter (Table 1$)$. There was very little difference $\left(<0.5^{\circ} \mathrm{C}\right)$ in bottom and surface water temperatures.

\section{Fauna}

One hundred cores were taken during early autumn and late winter 2000, yielding 17,443 benthic invertebrates and a total of 52 species. During early autumn, species richness of benthic invertebrates was low, consisting primarily of polychaetes, molluscs and crustaceans (Table 2). Together the three taxa accounted for 25 of the 27 species recorded and were also the most abundant. Five species comprised $88.4 \%$ of total mean density (Table 3): the bivalve Arthritica semen $\left(2457 \mathrm{~m}^{-2}\right)$; the polychaetes Capitella aff capitata $\left(1657 \mathrm{~m}^{-2}\right)$, Ceratonereis aequisetis $\left(404 \mathrm{~m}^{-2}\right)$, and Leitoscoloplos normalis $\left(298 \mathrm{~m}^{-2}\right)$, and the amphipod Corophitum minor $\left(840 \mathrm{~m}^{-2}\right)$.

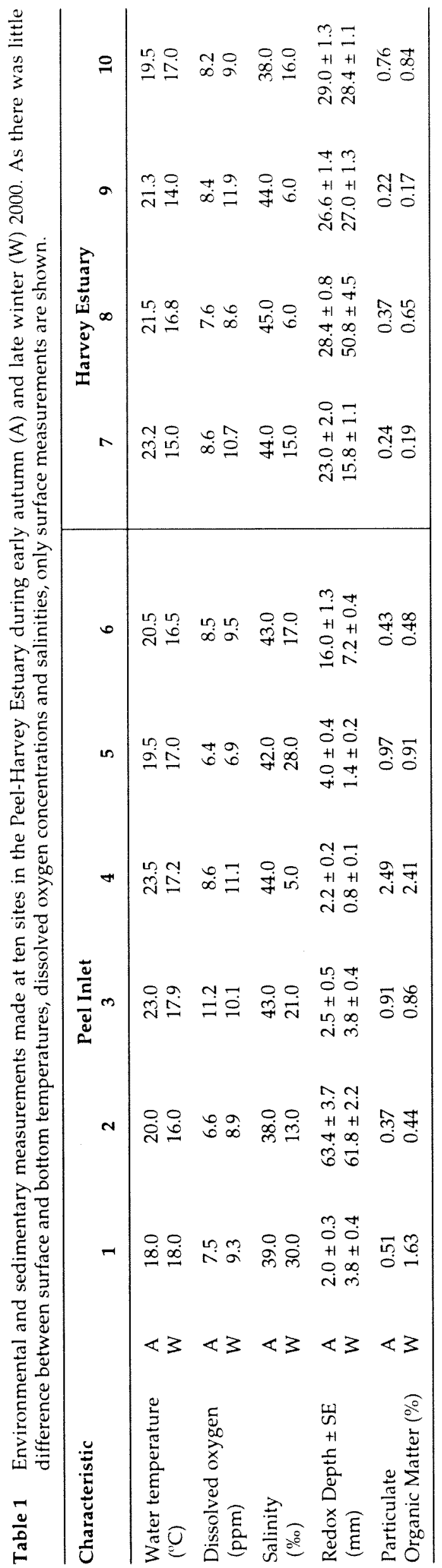


Table 2 Number of species, mean density and percentage contribution of major taxonomic groups in the Peel-Harvey Estuary during early autumn and late winter 2000

\begin{tabular}{|c|c|c|c|c|c|c|}
\hline Taxon & $\begin{array}{l}\text { Number } \\
\text { of Species }\end{array}$ & $\begin{array}{c}\text { Early Autumn } \\
\text { Mean Density } \mathrm{m}^{-2} \\
(\bar{X} \pm S E)\end{array}$ & $\begin{array}{c}\text { Contribution } \\
(\%)\end{array}$ & $\begin{array}{l}\text { Number } \\
\text { of Species }\end{array}$ & $\begin{array}{c}\text { Late Winter } \\
\left.\text { Mean Density } \mathrm{m}^{-2}\right) \\
(\bar{X} \pm \mathrm{SE})\end{array}$ & $\begin{array}{c}\text { Contribution } \\
(\%)\end{array}$ \\
\hline Polychaeta & 9 & $2777 \pm 272$ & 43.4 & 10 & $11,232 \pm 890$ & 42.9 \\
\hline Mollusca & 9 & $2587 \pm 711$ & 40.5 & 11 & $2545 \pm 444$ & 9.7 \\
\hline Crustacea & 7 & $1028 \pm 237$ & 16.1 & 18 & $8465 \pm 1621$ & 32.3 \\
\hline Insecta & 1 & $2 \pm 2$ & $>0.0$ & 3 & $3916 \pm 1107$ & 15.0 \\
\hline Coelenterata & 1 & $2 \pm 2$ & $>0.0$ & 2 & $10 \pm 5$ & $>0.0$ \\
\hline Priapulida & 0 & $0 \pm 0$ & $>0.0$ & 1 & $8 \pm 8$ & $>0.0$ \\
\hline Echinodermata & 0 & $0 \pm 0$ & $>0.0$ & 1 & $2 \pm 2$ & $>0.0$ \\
\hline Nemertea & 0 & $0 \pm 0$ & $>0.0$ & 1 & $2 \pm 2$ & $>0.0$ \\
\hline Total & 27 & $6397 \pm 1224$ & 100.0 & 46 & $26,180 \pm 4079$ & 100.0 \\
\hline
\end{tabular}

Species richness was substantially greater (46 species) in late winter. As in autumn, polychaetes, molluscs and crustaceans dominated, with an increase of 11 crustacean species. In addition, a single species each of priapulid, echinoderm and nermetean were found in late winter; none were recorded in early autumn. Total mean invertebrate density quadrupled to $26,180 \mathrm{~m}^{-2}$ in late winter compared to $6397 \mathrm{~m}^{-2}$ in early autumn. Molluscs had approximately the same density in early autumn and late winter, but polychaetes and crustaceans increased substantially, by $8455 \mathrm{~m}^{-2}$ and $7437 \mathrm{~m}^{-2}$ respectively. In contrast to their near absence in early autumn, the density of insects in late winter was $3416 \mathrm{~m}^{-2}$. In late winter the five most abundant species comprised only $73.5 \%$ of the total mean density. They were the polychaete Capitella aff capitata $\left(7015 \mathrm{~m}^{-2}\right)$, the amphipods Corophium minor $\left(4304 \mathrm{~m}^{-2}\right)$ and Paracorophium excavatum $\left(2129 \mathrm{~m}^{-2}\right)$, a chironomid larva $\left(3902 \mathrm{~m}^{-2}\right)$ and the bivalve Arthritica semen $\left(1895 \mathrm{~m}^{-2}\right)$

Distribution of species in the estuary was uneven (Table 4; Figure 1). In early autumn the number of species varied from one at Site 4 and two at Site 3 (South Yunderup) to 15 at Site 2 (Mandurah Entrance Channel); all of these sites are in Peel Inlet. Species were more evenly distributed throughout all sites in the Harvey Estuary, ranging from seven species at Site 7 (Mealup Point) to nine species at Site 10. With the exception of Site 9, all other sites had more species in late winter. There was also an increased variability in species distributions. In Peel Inlet, the number of species ranged from eight at Site 4 to 26 at Site 6 . The range in the Harvey Estuary was from six species at Site 9 to 23 species at Site 8 (Point Repose).

Similarly, there were considerable variations in the total invertebrate density between sites (Table 4; Figure 1). The minimum total mean density recorded in early autumn was $20 \mathrm{~m}^{2}$ at Site 4 in Peel Inlet; the maximum was $24,690 \mathrm{~m}^{-2}$ at Site 9 in the Harvey Estuary. In contrast to species richness, total mean density variations in the Harvey Estuary were greater in early autumn (from $1060 \mathrm{~m}^{-2}$ at Site 10 to $24,690 \mathrm{~m}^{-2}$ at Site 9) than in Peel Inlet $\left(20 \mathrm{~m}^{-2}\right.$ at Site 4 to $9824 \mathrm{~m}^{-2}$ at Site 5). Total mean densities increased in late winter at all sites except Site 9 in the Harvey Estuary, where density decreased from $24,690 \mathrm{~m}^{-2}$ to $13,705 \mathrm{~m}^{-2}$. Mean invertebrate density at Site 8 in the Harvey Estuary increased by 26 -fold, from $2201 \mathrm{~m}^{-2}$ in early autumn to $58,083 \mathrm{~m}^{-2}$ in late winter. Densities at Sites 3 and 6 in Peel Inlet also increased by over an order of magnitude. The greatest percentage increase occurred at Site 4 in Peel Inlet, where densities increased by nearly three orders of magnitude, from $20 \mathrm{~m}^{-2}$ to $17,287 \mathrm{~m}^{-2}$. There was no clear relationship between invertebrate density and proximity to the Dawesville Channel. In particular, Site 6 near the northern end of the Harvey Estuary had a total mean density of $53,942 \mathrm{~m}^{-2}$ in late winter, while the nearby Site 10 at the entrance to the Dawesville Channel had a total mean density of only $8403 \mathrm{~m}^{-2}$.

Most of the increase in total mean density in late winter was due to five species: the polychaete Capitella aff capitata increased in mean density from $1657 \mathrm{~m}^{-2}$ in early autumn to $7015 \mathrm{~m}^{-2}$ in late winter; the amphipods Corophium minor from $840 \mathrm{~m}^{-2}$ to $4304 \mathrm{~m}^{-2}$ and Paracorophitum excavatum from $0 \mathrm{~m}^{-2}$ to $2129 \mathrm{~m}^{-2}$; an unidentified chironomid larva from $0 \mathrm{~m}^{-2}$ to $3902 \mathrm{~m}^{-2}$; and the isopod Tanais dulongi from $0 \mathrm{~m}^{-2}$ to $998 \mathrm{~m}^{-2}$. Except for the chironomid larva, all of these are estuarine species. The estuarine bivalve Arthritica semen decreased in density from $2457 \mathrm{~m}^{2}$ in early autumn to $1895 \mathrm{~m}^{-2}$ in late winter.

Cluster analysis indicated there were no clear community differences in the invertebrate community in different parts of the estuary (Figure 2). In early autumn there was some separation of invertebrate communities in the Peel Inlet and Harvey Estuary between Sites 6 and 10, near the entrance to the Dawesville Channel. Site 4 in Peel Inlet was the exception, due to the occurrence of only one species at this site, Anthicidae sp., a 
Table 3 Mean density of benthic invertebrate species collected in the Peel-Harvey Estuary during early autumn and late winter 2000 .

$\begin{array}{cc}\text { Taxon } & \text { Mean Density } \mathrm{m}^{-2}(\overline{\mathrm{X}} \pm \mathrm{SE}) \\ \text { Late Winter }\end{array}$

\section{POLYCHAETA}

Australonereis ehlersi Augener, 1913

Boccardiella limnicola Blake \& Woodwick, 1976

Capitella aff capitata Fabricius, 1780

Ceratonereis aequisetis Auginer, 1913

Heteromastus filiformis (Claparede, 1864)

Laonome sp.

Leitoscoloplos normalis Day, 1977

Marphysa sanguinea Montague, 1815

Nephtys gravieri Auginer, 1913

Nephtys longpipes Stimpson, 1856

Spirorbidae sp.

Total Polychaetes

\section{MOLLUSCA}

Bivalvia

Arthritica semen (Menke, 1843)

Donax columbella Lamarck, 1818

Sanguinolaria biradiata (Wood, 1815)

Spisula trigonella (Lamarck, 1818)

Tellina deltoidalis Lamarck, 1818

\section{Gastropoda}

Acteocina sp.

Assiminea sp.

Hydrococcus brazieri (T. Woods, 1876)

Cephalaspidean sp.

Nassarius burchardi (Philippi, 1849)

Hydrobia buccinoides (Quoy \& Gaimard, 1834)

Patella peronii Blainville, 1825

Total Molluscs

\section{CRUSTACEA}

\section{Isopoda}

Cirolana sp.

Cruranthura simplicia Thomson, 1946

Gastrosaccus sp.

Munna brevicornis (Thomson, 1946)

Tanais dulongi Thomson, 1944

\section{Copepoda}

Harpacticoida sp.

\section{Amphipoda}

Allorchestes cf. compressa Dana, 1852

Caprella scaura Templeton, 1836

Corophium minor (Thomson, 1946)

cf. Erichthonius sp.

Grandidierella sp.

Lysianassidae sp.

Melita matilda J.L. Barnard, 1972

Melita zeylanica J.L. Barnard, 1972

Paracorophium excavatum (Thomson, 1884)

Parelasmopus sp.

Tethygenia elanora J.L. Barnard, 1972

\section{Decapoda}

Galathea sp.

cf. Metapenaeus dalli Racek, 1957

cf. Penaeus latisulcatus Kishinouye, 1896

Total Crustaceans

$$
\begin{gathered}
170 \pm 56 \\
108 \pm 30 \\
1657 \pm 224 \\
404 \pm 93 \\
52 \pm 19 \\
66 \pm 14 \\
298 \pm 69 \\
12 \pm 7 \\
10 \pm 5 \\
0 \pm 0 \\
0 \pm 0
\end{gathered}
$$$$
2777 \pm 272
$$

$812 \pm 200$

$326 \pm 93$

$7015 \pm 839$

$856 \pm 133$

$22 \pm 8$

$1056 \pm 214$

$812 \pm 112$

$6 \pm 4$

$0 \pm 0$

$4 \pm 3$

$322 \pm 109$

$11,232 \pm 890$

$$
\begin{gathered}
2457 \pm 711 \\
0 \pm 0 \\
2 \pm 2 \\
4 \pm 3 \\
2 \pm 2
\end{gathered}
$$

$$
\begin{aligned}
1895 & \pm 421 \\
12 & \pm 6 \\
2 & \pm 2 \\
344 & \pm 104 \\
26 & \pm 10
\end{aligned}
$$

$$
\begin{gathered}
80 \pm 43 \\
8 \pm 4 \\
30 \pm 15 \\
0 \pm 0 \\
2 \pm 2 \\
0 \pm 0 \\
2 \pm 2
\end{gathered}
$$$$
72 \pm 29
$$

$2587 \pm 711$

$26 \pm 8$

$134 \pm 40$

$10 \pm 4$

$16 \pm 7$

$8 \pm 5$

$0 \pm 0$

$2545 \pm 444$

$0 \pm 0$

$2 \pm 2$

$80 \pm 26$

$10 \pm 5$

$0 \pm 0$

$998 \pm 375$

$0 \pm 2$

$0 \pm 0$

$26 \pm 12$

$0 \pm 0$

$10 \pm 4$

$42 \pm 19$

$840 \pm 205$

$0 \pm 0$

$0 \pm 0$

$4304 \pm 1226$

$12 \pm 12$

$638 \pm 119$

$2 \pm 2$

$2 \pm 2$

$174 \pm 47$

$0 \pm 0$

$28 \pm 13$

$0 \pm 0$

$0 \pm 0$

$0 \pm 0$

$2129 \pm 785$

$64 \pm 64$

$4 \pm 3$

$0 \pm 0$

$2 \pm 2$

$0 \pm 0$

$0 \pm 0$

$2 \pm 2$

$6 \pm 6$

$1028 \pm 237$ 
Taxon

Mean Density $m^{-2}(X \pm S E)$ Early Autumn

Late Winter

\section{INSECTA}

Anthicidae sp.

Chironomidae sp. (larva)

Diptera sp.1 (larva)

$2 \pm 2$

$0 \pm 0$

$0 \pm 0$

$0 \pm 0$

$2 \pm 2$

$0 \pm 0$

Diptera sp.2 (larva)

$3902 \pm 1106$

$10 \pm 7$

$4 \pm 4$

Total Insects

$2 \pm 2$

$0 \pm 0$

$8 \pm 5$

Haliplanella lnciae (Verrill, 1898)

Pennatulacean sp

$2 \pm 2$

PRIAPULIDA

cf. Priapulus sp.

$0 \pm 0$

$8 \pm 8$

ECHINODERMATA

Astropecten sp.

$0+0$

$2 \pm 2$

NEMERTEA

Nemertean sp.

$0 \pm 0$

$2 \pm 2$

\begin{tabular}{ccc}
\hline Overall Total & $6397 \pm 1224$ & $26,180 \pm 4079$ \\
\hline
\end{tabular}

AUTUMN
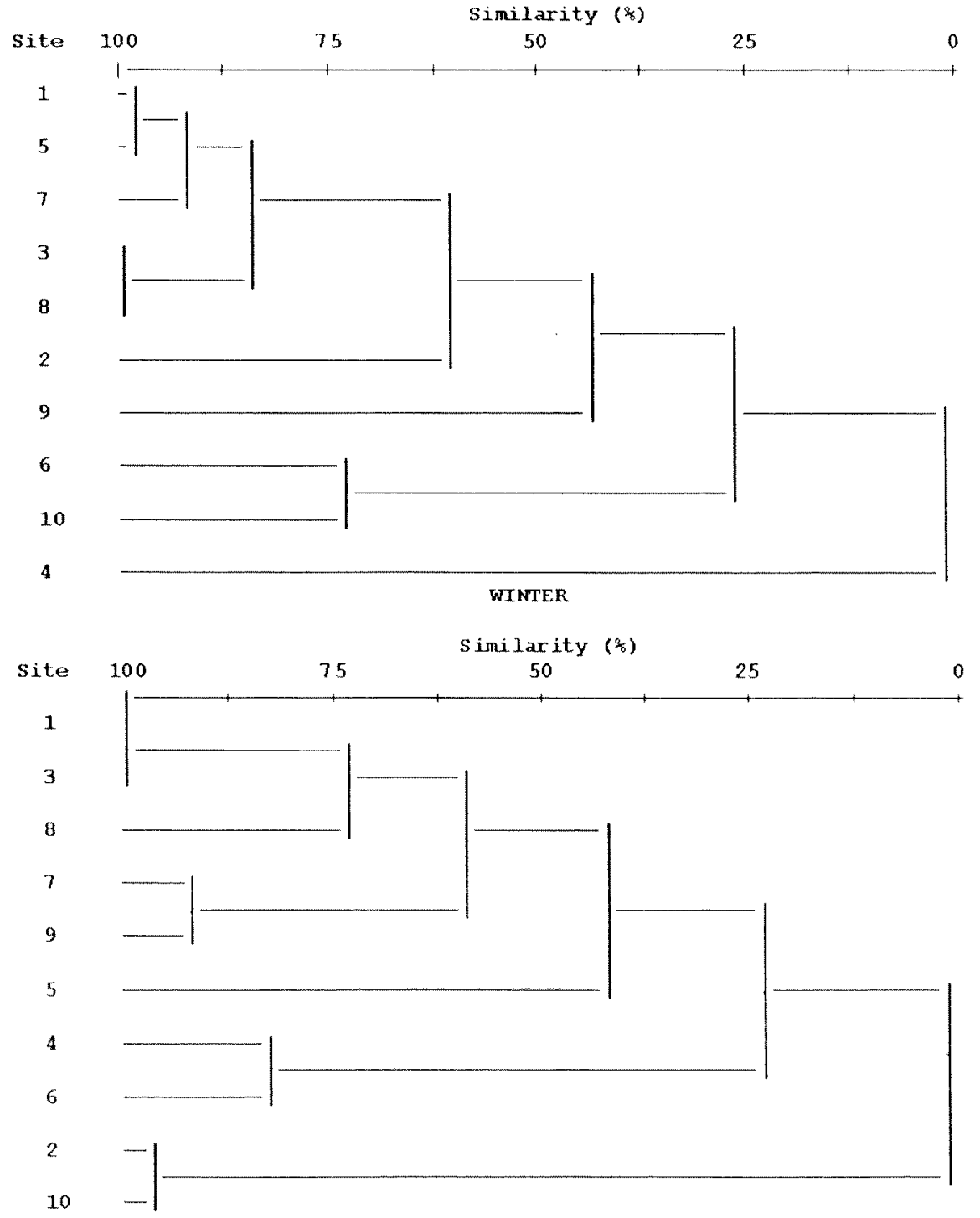

Figure 2 Dendogram of sampling sites during early autumn and late winter 2000. 


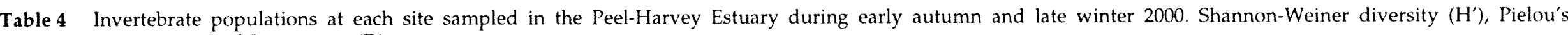
evenness (E) and Dominance (D).

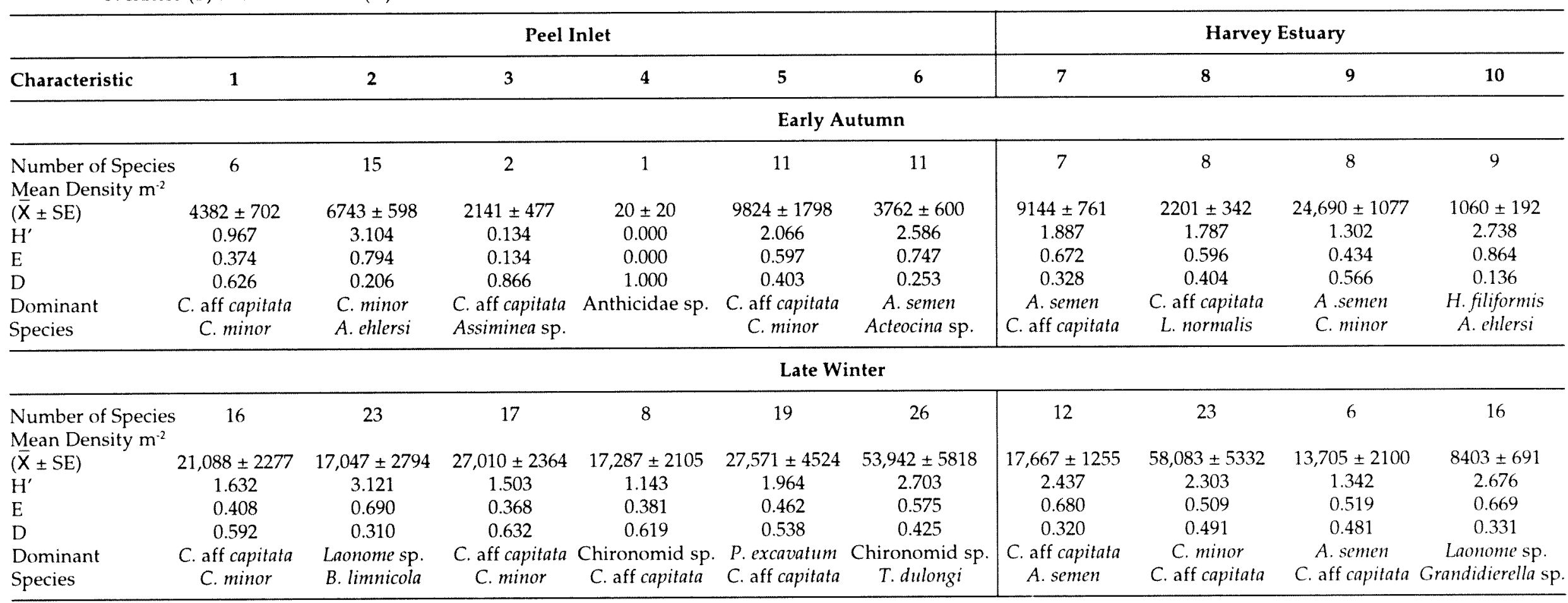


species that did not occur elsewhere. The separation between sites in Peel Inlet and in the Harvey Estuary from those near the Dawesville Channel did not occur in late winter (Figure 2). There was a slight separation between Site 10, at the entrance to the Dawesville Channel, and Site 2 at the entrance to the Mandurah Channel from those further into the estuaries, but Site 6 (near Site 10) was not in this grouping

\section{DISCUSSION}

The benthic invertebrate assemblage in the PeelHarvey Estuary had low species richness (27 species) in early autumn. Species richness was substantially greater (46 species) in late winter. Total mean density quadrupled from $6397 \mathrm{~m}^{-2}$ in early autumn to $26,180 \mathrm{~m}^{2}$ in late winter and there were no clear differences in community structure in the system in either season. Polychaetes, molluscs and crustaceans dominated species numbers and density in both seasons. The increased species richness in late winter was primarily due to an increase in diversity of small crustaceans with a short life-span (isopods and amphipods) and, to a lesser extent, a chironomid larvae. Thus there is a clear difference of benthic invertebrate species richness and density between the autumn and winter seasons. With the exception of Site 9 (at the southern end of the Harvey Estuary) the increase in density was consistent throughout both Peel Inlet and the Harvey Estuary; there was no apparent correlation between increased densities and proximity to the entrance channels.

Comparison of the present results with benthic invertebrate populations prior to the construction of the Dawesville Channel is difficult as there is little published data available. The best data are those of a three-year study of molluscs conducted during the late 1970's (Wells et al., 1980), at a time when massive amounts of the green macroalga Cladophora were present in the system. Mollusc diversity was low (Wells et al., 1980; Wells and Threlfall, 1980; 1981), and was dominated by two small estuarine species: the bivalve Arthritica semen and the gastropod Hydrococcus brazieri, which together accounted for almost all of total molluse density on sand in the Peel-Harvey Estuary. Both were found to be small, short-lived species with successful reproductive strategies suitable for estuarine conditions (i.e. fast maturation, continuous egg production and direct development enabling release of juveniles during optimum estuarine conditions). The populations were also highly productive, but densities varied greatly (Wells and Threllfall, 1982a; 1982b; 1982c). A twovear study undertaken at Coodanup in Peel Inlet (near Site 1) from March 1977 to February 1979 recorded a maximum density of $45,491 \mathrm{~m}^{2}$ (mean
$8105 \mathrm{~m}^{-2}$ ) for A. semen and $19,959 \mathrm{~m}^{2}$ (mean $\left.9487 \mathrm{~m}^{2}\right)$ for H. brazieri.

The middle regions of the Peel-Harvey Estuarine basins were sampled by Rose (1994) in 1986-87, before the Dawesville Channel was constructed. He sampled two sites each in the Peel Inlet and northern Harvey Estuary and recorded 37 species, with macrobenthic densities being highest in autumn and lowest in summer. The benthic fauna in 1986-87 was dominated by small, short-lived opportunist species with successful reproductive strategies suitable for estuarine conditions, eg. the polychaete Capitella aff capitata, amphipod Corophitum minor and bivalve Arthritica semen. Hydrocuccus brazieri was absent in the middle regions of Peel Inlet and, compared to previous sampling (Wells and Threllfall, 1982a; 1982b; 1982c), the density of $A$. semen had decreased, particularly in Peel Inlet. An extensive search failed to reveal any live $H$. brazieri. These low densities were attributed to the deleterious effects of macroalgal and Nodularia spumigena decomposition.

The samples taken in 2000 recorded system-wide mean densities of $30 \mathrm{~m}^{-2}$ for $H$. brazieri in early autumn and $134 \mathrm{~m}^{-2}$ in late winter, compared with a similar survey undertaken in January $\left(122 \mathrm{~m}^{-2}\right)$ and August $1978\left(835 \mathrm{~m}^{-2}\right)$ before the Dawesville Channel was opened. The system-wide mean densities of $A$. semen in early autumn and late winter 2000 were $2457 \mathrm{~m}^{-2}$ and $1895 \mathrm{~m}^{-2}$ respectively; compared with January $\left(7175 \mathrm{~m}^{-2}\right)$ and August $\left(1937 \mathrm{~m}^{2}\right) 1978$. Whilst the present-day distribution of both species resembles that recorded in the 1970's (Wells and Threllfall, 1982c) densities have remained low since the Dawesville Channel was opened. The reappearance of both species may be attributed to the absence of Nodularia spumigena blooms since the opening of the Dawesville Channel and reduced decomposition and smothering by macroalgae, which began to decline in the early 1990's (Hale and Paling, 1999).

The present study recorded a total of 52 species of benthic invertebrates; considerably higher than previous studies undertaken prior to the opening of the Dawesville Channel. Chalmer and Scott (1984) and Rose (1994) found 25 and 37 species respectively. Several marine species were recorded in 2000 that were not common or recorded prior to the opening of the Dawesville Channel, including the molluscs Donax columbella, Nassarius burchardi, Patella peronii and a cephalaspidean species. All of these species were recorded in very low densities, and they have not established the dense populations previously attained by $H$. brazieri.

The Dawesville Channel appears to allow greater access for planktonic larvae to enter the system (as opposed to the narrow shallow Mandurah Entrance Channel) and combined with the increase in salinities during winter, allows marine species, at 
least initially, to settle and colonise areas in the estuary in late winter. Seasonal density patterns of benthic invertebrates in this study were different to previous studies by Rose (1994), suggesting the effects of eutrophication are less severe since the Dawesville Channel was constructed. Whether these new marine "non-estuarine" species can survive throughout the year has not yet been determined, although autumn data presented in this study suggests that few of these species maintained their earlier populations. Other factors such as biological interactions eg. fish predation, and benthic competition, may now also influence seasonal density patterns.

\section{ACKNOWLEDGEMENTS}

This paper is modified from a BSc (Hons) thesis undertaken at Curtin University of Technology by the senior author. We are pleased to acknowledge the considerable assistance of the internal supervisor at Curtin, Dr Rob Rippingale. Drs Anne Brearley of The University of Western Australia and Karen Hillman of DAL Science \& Engineering kindly commented on a draft of the manuscript. The senior author wishes to extend his gratitude to Angela Schumacher, who assisted in field and laboratory work and provided support and encouragement.

\section{REFERENCES}

Barnes, R. S. K. (1974). Estuarine Biology. Institute of Biology, Edward Arnold Publishers, London. Studies in Biology, No. 49: 1-76.

Chalmer, P. N., and Scott, J. K. (1984). Fish and benthic faunal surveys of the Leschenault and Peel-Harvey estuarine systems of south-western Australia in December 1984. Western Australian Department of Conservation and Environment, Bulletin 149.

Day, J. H. (1981). Estuarine ecology with particular reference to South Africa. A.A. Balkema, Cape Town.

Hale, J., and Paling, E. (1999). Water Quality of the Peel Harvey Estuary: Comparisons before and after the opening of the Dawesville Channel (June 1985 to July 1999). Marine and Freshwater Research Laboratory, 99/4 (Water and Rivers Commission).

Hesp, P. A. (1984). Aspects of the geomorphology of south-western Australian estuaries (pp. 61-83). In: Hodgkin, E.P (ed.) Estuarine environments of the Southern Hemisphere. Western Australian Department of Conservation and Environment, Bulletin 161.

Hodgkin, E. P., and DiLollo, V. (1958). Tides of southwestern Australia. Journal of the Royal Society of Western Australia, 41: 42-51.

Hodgkin, E. P., and Lenanton, R. C. J. (1981). Estuaries and coastal lagoons of south-western Australia (pp. 307-321). In: Neilson, B.J. and Cronin, L.E. (eds.) Estuaries and Nutrients. Humana Press, Clifton, New Jersey.
Hodgkin, E. P., and Hesp, P. A. (1998). Estuaries to salt lakes: Holocene transformation of the estuarine ecosytems of south-western Australia. Marine and Freshwater Research, 49: 183-201.

Hodgkin, E. P., Birch, P. B., Black, R. E., and Hillman, K. (1985). The Peel-Harvey Estuarine System: proposals for management. Western Australia Department of Conservation and Environment, Bulletin 14: 1-54.

Holme, N. A., and Mclntyre, A. D. (1984). Methods for the study of marine benthos. Blackwell Scientific Publications, London.

Krebs, C. J. (1989). Ecological methodology. Harper and Row, Publishers. New York

McComb, A. J., and Lukatelich, R. J. (1995). The PeelHarvey Estuarine System, Western Australia (pp. 5 17). In: McComb, A.J. (ed.) Eutrophic shallow estuaries and lagoons. CRC Press, London.

McLusky, D. S. (1989). The estuarine ecosystem. Second edition. Blackie, USA. Chapman and Hall, New York.

Rippingale, R. J. (1977). An introductory study of water exchange in the Peel Inlet from December 1976 to February 1977. Department of Conservation and Environment. Report to the Estuarine and Marine Advisory Committee, $70 \mathrm{pp}$.

Rose, T. H. (1994). Comparisons of the benthic and zooplankton communities in the eutrophic Peel-Harvey and nearby Swan Estuaries in south-western Australia. Unpublished PhD Thesis, Environmental Science, Murdoch University, $267 \mathrm{pp}$.

Wells, F. E., Threlfall, T. J., and Wilson, B. R. (1980). The Peel-Harvey estuarine system study (1976-1980). Biology of Molluscs. Western Australian Department of Conservation and Environment, Bulletin 97: 1-106.

Wells, F. E., and Threlfall, T. J. (1980). A comparison of molluscan communities on intertidal sand flats in Oyster Harbour and Peel Inlet, Western Australia. Journal of Molluscan Studies, 46: 300-311.

Wells, F. E., and Threlfall, T. J. (1981). The molluscs of Peel Inlet, Western Australia, and a comparison with other south-western estuaries. Journal of the Malacological Society of Australia, 5: 100-111.

Wells, F. E., and Threlfall, T. J. (1982a). Salinity and temperature tolerance of Hydrococcus brazieri ( $\mathrm{T}$. Woods, 1876) and Arthritica semen (Menke, 1843) from the Peel- Harvey estuarine system, Western Australia. Journal of the Malacological Society of Australia, 5: 151156.

Wells, F. E., and Threlfall, T. J. (1982b). Reproductive strategies of Hydrococcus brazieri and Arthritica semen in Peel Inlet, Western Australia. Journal of the Malacological Society of Australia, 5: 157-166.

Wells, F. E., and Threlfall, T. J. (1982c). Density fluctuations, growth and production of Hydrococcus brazieri and Arthritica semen in the Peel-Harvey estuarine system, Western Australia. Journal of Molluscan Studies, 48: 310-320.

Manuscript received 7 April 2003; accepted 24 October 2003 